\begin{tabular}{|c|c|c|c|c|c|c|}
\hline \multirow{4}{*}{ Impact Factor: } & ISRA (India) & $=3.117$ & SIS (USA) & $=0.912$ & ICV (Poland) & $=6.630$ \\
\hline & ISI (Dubai, UAE & $=\mathbf{0 . 8 2 9}$ & РИНЦ (Russia & $=0.156$ & PIF (India) & $=1.940$ \\
\hline & GIF (Australia) & $=0.564$ & ESJI (KZ) & $=\mathbf{5 . 0 1 5}$ & IBI (India) & $=4.260$ \\
\hline & JIF & $=1.500$ & SJIF (Morocco & $=5.667$ & OAJI (USA) & $=0.350$ \\
\hline
\end{tabular}

\begin{tabular}{|c|c|}
\hline $\begin{array}{l}\text { SOI: } \frac{1.1 / \mathrm{T}}{\mathrm{S}} \\
\text { International Sc} \\
\text { Theoretical } \boldsymbol{\&}\end{array}$ & 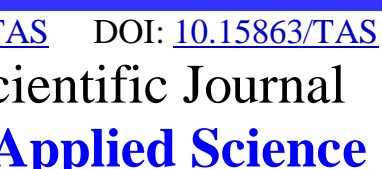 \\
\hline p-ISSN: 2308-4944 (print) & e-ISSN: 2409-0085 (online) \\
\hline Year: 2019 & Volume: 69 \\
\hline Published: 30.01 .2019 & http://T-Science.org \\
\hline
\end{tabular}

SECTION 31. Economic research, finance, innovation, risk management.
QR - Issue

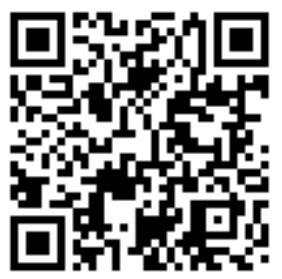

Komiljon Zoitovich Khomitov

Professor of department "Valuation and investments" of Tashkent institute of Finance, Doctor of Economics

\title{
CURRENT ISSUES OF CREDITING INVESTMENT PROJECTS IN UZBEKISTAN
}

Abstract: This article analyzes the current state of lending to the economy as a whole and lending to investment projects in Uzbekistan, as well as discusses a range of current issues. The author has analyzed in detail gross loans and investment loans of commercial banks of the Republic of Uzbekistan for 2013-2018. The article scientifically substantiates that at present the mandatory reserve rates are one of the limiting factors for the further growth of lending to investment projects.

Key words: guarantee, investment, investment project, investment loan, commercial bank, loan, interest rate, resource base, refinancing rate.

Language: English

Citation: Khomitov, K. Z. (2019). Current issues of crediting investment projects in Uzbekistan. ISJ Theoretical \& Applied Science, 01 (69), 335-339.

Soi: http://s-o-i.org/1.1/TAS-01-69-47 Doi: crostef https://dx.doi.org/10.15863/TAS.2019.01.69.47

\section{Introduction}

With independence, Uzbekistan pursues its own independent domestic and foreign policy, based on the traditions and historical past of the Uzbek people, geographical location and accumulated economic potential.

The Government of the Republic of Uzbekistan pays special attention to improving the investment climate and creating favorable conditions for attracting foreign investment in the economy of the republic, active participation of foreign investors in the process of privatization and denationalization, in the production of products competitive on international markets.

An effective tool for structural transformations of the priority sectors of the economy of the republic is the state policy on attracting foreign investment. Attraction and targeted use of foreign investment in the economy of our country is one of the directions of mutually beneficial economic cooperation between countries. With the help of foreign investments, it is possible to improve the production structure of the economy, create new high-tech industries, create new jobs, modernize fixed assets and technically re-equip many enterprises, train specialists and workers, introduce advanced management, marketing and know-how achievements, fill the domestic market with high- quality goods domestic production with absolute energy independence. Subsoil simultaneous increase in exports to foreign countries.

\section{Main part}

The Republic of Uzbekistan is one of the few countries in the world whose economy is characterized by Uzbekistan possessing enormous reserves of minerals and natural resources. The country occupies a leading position in the world in terms of gold, uranium, copper, silver, lead, zinc, tungsten, rare metals and other stocks.

Our country is among the top ten countries in terms of gas and oil reserves, coal and uranium. Electricity produced in the country at a cost is 4 times lower than the average price paid by industrial consumers in developed countries. Uzbekistan also has the most diversified economy in Central Asia. Uzbekistan is the only state in Central Asia that produces a wide range of modern cars, trucks, highquality agricultural equipment: from mini-tractors to combines, the largest producer in the region of chemical, textile, food products, building materials, electronics and electrical engineering.

Under the leadership of our country's President Shavkat Mirziyoyev, large-scale reforms are being implemented to attract foreign investment and create even more optimal conditions for doing business. In 


\begin{tabular}{|c|c|c|c|c|c|c|}
\hline \multirow{4}{*}{ Impact Factor: } & ISRA (India) & $=3.117$ & SIS (USA) & $=0.912$ & ICV (Poland) & $=6.630$ \\
\hline & ISI (Dubai, UAE & $=0.829$ & РИНЦ (Russia) & $=0.156$ & PIF (India) & $=1.940$ \\
\hline & GIF (Australia) & $=0.564$ & ESJI (KZ) & $=5.015$ & IBI (India) & $=4.260$ \\
\hline & JIF & $=1.500$ & SJIF (Morocco) & $=5.667$ & OAJI (USA) & $=0.350$ \\
\hline
\end{tabular}

the process of liberalizing the economy, improving the investment climate in our country takes priority. As you know, the President of the Republic of Uzbekistan on February 7, 2017 approved a comprehensive Decree "On the Strategy for Action on the Further Development of the Republic of Uzbekistan in 2017-2021", which also provides for the task of expanding credit for promising projects of small businesses and private entrepreneurship, effective use of attracted foreign investments and loans in the Republic of Uzbekistan.

In the national economy, the banking system is the most important institution that ensures overall economic stability and the safety of its development. World experience shows that the full development of banking infrastructure gives a decisive impetus to the growth of the national economy. Through banking systems, the largest investment resources are formed and the states are interested in their direction for the needs of the national economy.

As the President of the Republic of Uzbekistan Sh. Mirziyoyev noted, "A reliable and stable banking and financial system plays an important role in the development of the economy. Without increasing the confidence of the population and business entities, we will not be able to completely free ourselves from the "shadow" economy "[1]. In 2018, the implementation of the set objectives for the development of the banking system should focus on ensuring fruitful and mutually beneficial cooperation between banks and business entities, in particular in credit relations.

As evidenced by the experience of highly developed countries of the world, mid-term and long-term loans of commercial banks are an important source of financing investment projects.

In Uzbekistan, much attention is also paid to the development of lending to investment projects through long-term investment loans from commercial banks. The category of medium-term loans in the country is missing.

Increased investment activities of commercial banks due to the active investment policy of the state. So, in 2015, investments were attracted and mastered from all sources of financing in the equivalent of 15.8 billion USD, or with growth against 2014 , by $9.5 \%$. Over $21 \%$ of all investments are foreign investments, while $73 \%$ of foreign investments were foreign direct investment [2]. There many researches in management of enterprises and invetment as well as Tursunov B. [8], Karimov N.G., Tashxojaev M., [9]. Ishina I. V., Sazonova M. N. [10] and others.

Sustainable progress of the country along the path of democratic transformations, ensuring the stability of economic growth, reliable protection of the interests of private entrepreneurship, and progressive reduction of the state's presence in the economy contribute to increasing the investment attractiveness of Uzbekistan for foreign investors.

It is important to note that the main part of attracted investments is directed to the implementation of projects for the modernization, technical and technological renewal of branches of the real sector of the economy of the republic.

Below we consider the dynamics of credit investments and the level of long-term loans of commercial banks of the country (Table 1).

Table 1. Gross loans and investment loans of commercial banks of the Republic of Uzbekistan [3]

\begin{tabular}{|c|c|c|c|c|c|c|c|}
\hline \multirow[t]{2}{*}{ Indicators } & \multicolumn{6}{|c|}{ Years } & \multirow{2}{*}{$\begin{array}{l}\text { Change in } 2018 \\
\text { compared to } 2013\end{array}$} \\
\hline & 2013 & 2014 & 2015 & 2016 & 2017 & 2018 & \\
\hline Credits-gross trillion. Sum & 20,4 & 26,5 & 33,5 & 42,7 & 53,4 & 69,9 & 3,4 times \\
\hline Investment loans, trillion. sum & 15,7 & 8,5 & 10,2 & 12,2 & 32,0 & 41,0 & 2,6 times \\
\hline
\end{tabular}

As it becomes obvious from the data in the table, in 2013-2018 the amount of long-term loans from commercial banks of Uzbekistan tended to grow. This indicates that banks pay special attention to the provision of investment loans, in particular, the large banks of the republic are actively involved in financing significant investment projects.

The steady growth of the resource base of commercial banks contributes to an increase in the volume of long-term loans directed to the real sector of the economy. Thus, as of January 1, 2018, the total amount of credit investments of commercial banks of the Republic of Uzbekistan amounted to 66.9 trillion. soum, which is $30.9 \%$ more than in 2017. It is important to emphasize that the share of long-term loans in the total volume of credit investments of banks was equal to $58.7 \%$ [3].

Meanwhile, there are a number of actual 


\begin{tabular}{|c|c|c|c|c|c|c|}
\hline \multirow{4}{*}{ Impact Factor: } & ISRA (India) & $=3.117$ & SIS (USA) & $=0.912$ & ICV (Poland) & $=6.630$ \\
\hline & ISI (Dubai, UAE & $=0.829$ & РИНЦ (Russia) & $=0.156$ & PIF (India) & $=1.940$ \\
\hline & GIF (Australia) & $=0.564$ & ESJI (KZ) & $=5.015$ & IBI (India) & $=4.260$ \\
\hline & JIF & $=1.500$ & SJIF (Morocco) & $=5.667$ & OAJI (USA) & $=0.350$ \\
\hline
\end{tabular}

problems associated with improving the practice of lending to investment projects. In particular, in the banking practice of the republic, the necessary tools for effective credit risk management are not widely used, since it is well known that effective credit risk firstly, a guarantee is applied that is secured by the pledge of the guarantor's property, i.e. it is complemented by a pledge obligation. In case of confidence in the financial stability of the guarantor, an unsecured guarantee is used.

Secondly, upon receipt of a guarantee, the bank issuing the loan must ensure that the guarantor is ready to fulfill its obligation. To do this, foreign banks practice a mandatory conversation with the guarantor to confirm his intention to fulfill the guarantee obligation.

Thirdly, the guarantees should be properly executed and signed only by persons who have the authority to do so [5].

Meanwhile, in domestic practice, essentially, there are no mechanisms that stimulate the development of the productive investments of commercial banks. In Uzbekistan, for example, such generally accepted by world standards instruments as the preferential procedure for reserving attracted funds, as well as the special conditions for refinancing commercial banks for real investment projects, are not used.

In addition, there are difficulties with the qualitative selection of indicators necessary to conduct an objective assessment of potential borrowers, because it is from them that the result of the analysis of the financial statements of the enterprise depends, and, therefore, the risk group, to which they will later be assigned! " borrowers.

The coefficients used for the analysis can not always give an objective description of the financial condition of the borrower due to inflation, the characteristics of the transition state in the economy, the specifics of the borrower, depending on the industry sector. This, in turn, requires comparison with industry average indicators in the absence of information necessary for comparison.
The method of determining the repayment of a loan currently used in Uzbekistan is based only on the analysis of several key indicators (coverage ratio, liquidity ratio, autonomy ratio and dynamics of own circulating assets) and, if there are guarantors, the analysis is carried out on the same indicators. This technique does not give a full description of a potential borrower and does not take into account its "credit history", and also excludes such options, in which the borrowing company may lose its license (or work for an individual) or experience temporary difficulties in paying its debt to the bank. There are many other factors that are not taken into account by this methodology, which can lead not only to the formation of overdue debts from the borrower, but also to the crisis situation of the bank.

There is also a deterioration in the loan portfolio of banks as a result of an increase in the volume of policy loans. International practice shows that a large number of preferential policy loans can lead to an increase in the cost of lending to other subjects of the economy and reduce the quality of the loan portfolio of banks.

Comprehensive measures to liberalize monetary policy and the foreign exchange market, implemented in 2017, undoubtedly, have become one of the most important reforms in the monetary sphere. During 2017, the Central Bank and the Government of the country carried out extensive work in preparation for the liberalization of monetary policy. Starting from September 2017, the mechanism for determining the exchange rate of the national currency based on the demand and supply of foreign currency in the economy was introduced, and restrictions on the purchase, sale and disposal of foreign exchange funds previously established for the population and business entities were lifted.

It should be noted that the relatively high level of devaluation of the national currency, the sum, due to the liberalization of monetary policy, reduces the efficiency of lending to investment projects (Fig. $1)$. 


\begin{tabular}{|c|c|c|c|c|c|c|}
\hline \multirow{4}{*}{ Impact Factor: } & ISRA (India) & $=3.117$ & SIS (USA) & $=0.912$ & ICV (Poland) & $=6.630$ \\
\hline & ISI (Dubai, UAE & $=0.829$ & РИНЦ (Russia) & $=0.156$ & PIF (India) & $=1.940$ \\
\hline & GIF (Australia) & $=0.564$ & ESJI $(\mathrm{KZ})$ & $=\mathbf{5 . 0 1 5}$ & IBI (India) & $=4.260$ \\
\hline & JIF & $=1.500$ & SJIF (Morocco) & $=5.667$ & OAJI (USA) & $=0.350$ \\
\hline
\end{tabular}

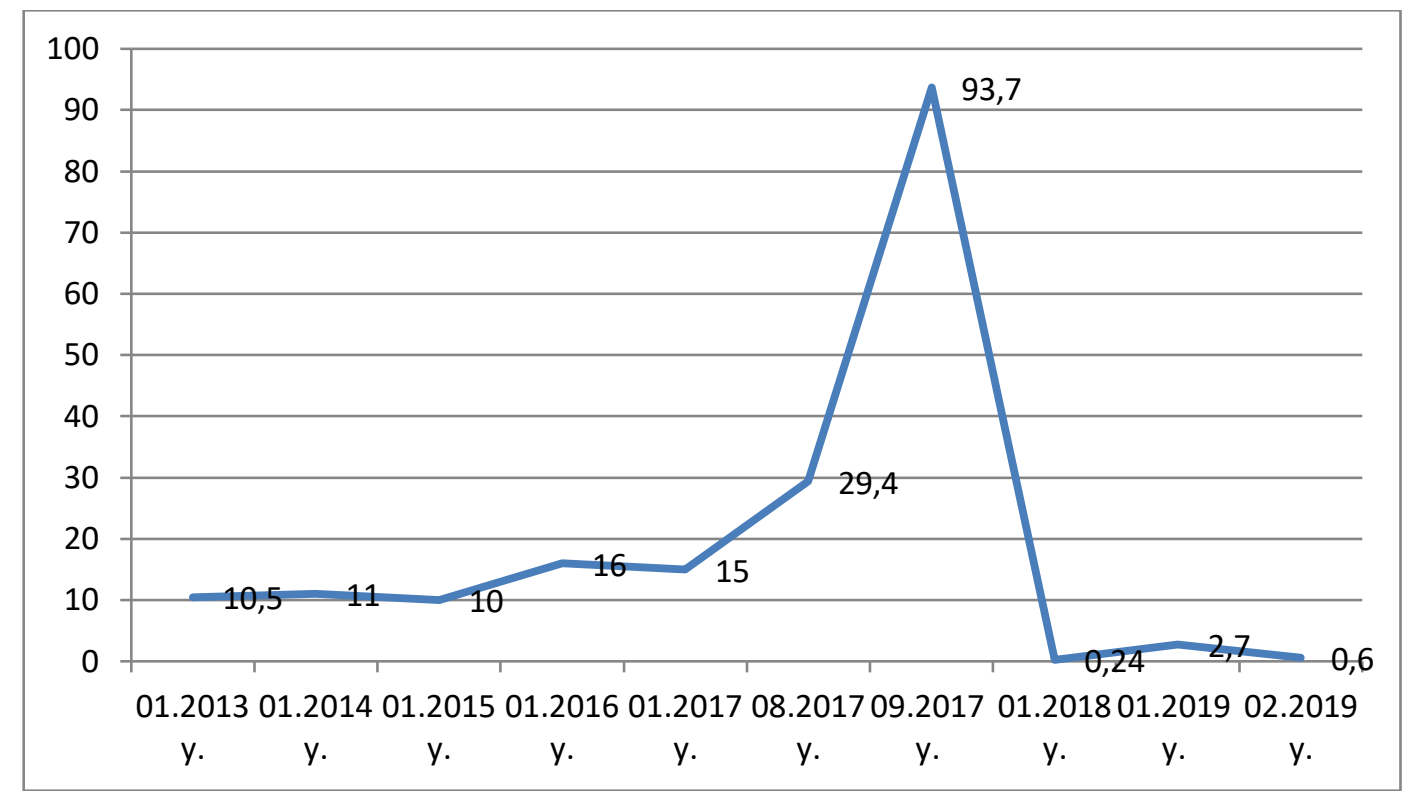

Fig. 1. The annual level of devaluation of the sum against the US dollar [6].

As is clear from the figure, the annual level of devaluation of the sum remains at a relatively high level, as a result of which the effectiveness of lending to investment projects decreases.

\section{Conclusion}

In conclusion, it should be emphasized that the banks in the country have a shortage of long-term resources required for lending to investment projects. The main share of banking resources is occupied by balances in current customer accounts. The investment potential of bank deposits is limited, since they are placed for a short period in order to preserve capital and cannot be invested by commercial banks in financing long-term loans. Therefore, a reduction in the rate of mandatory reserves of the Central Bank of the Republic of Uzbekistan is important for domestic banks.

Along with this, there are problems associated with the effective use of received international loans. As rightly noted by the President of the Republic of Uzbekistan Sh.M. Mirziyoev, "the loans of international financial institutions are used ineffectively, especially in the systems of the Republican Road Fund and the Uzkommunkhizmat agency acting as project customers" [7].

Moreover, the development of the economy is hampered by serious mistakes in the definition and implementation of promising large projects, the irrational direction of foreign loans. For example, according to experts and specialists, most of the loans received over 25 years did not produce the planned economic effect. For example, the Ustyurt gas-chemical complex built in Karakalpakstan does not bring the expected economic benefits [1].

Currently, the required reserve rates remain at a fairly high level, which is a deterrent to the further growth of lending to investment projects.

Also necessary to improve the efficiency of the process of accumulating free cash of legal entities and individuals and their transformation into investments. However, the transformation process is slow.

\section{References:}

1. (2018). Message from the President of the Republic of Uzbekistan Shavkat Mirziyoyev to the Oliy Majlis. (p.96). Tashkent: Uzbekistan.
2. Allen, F., \& Gale, D. (2000). Comparing Financial Systems. (p.519). Cambridge, Mass.: MIT Press. 


\begin{tabular}{|c|c|c|c|c|c|c|}
\hline \multirow{4}{*}{ Impact Factor: } & ISRA (India) & $=3.117$ & SIS (USA) & $=0.912$ & ICV (Poland) & $=6.630$ \\
\hline & ISI (Dubai, UAE & $=0.829$ & РИНЦ (Russia) & $=0.156$ & PIF (India) & $=1.940$ \\
\hline & GIF (Australia) & $=0.564$ & ESJI (KZ) & $=5.015$ & IBI (India) & $=4.260$ \\
\hline & JIF & $=1.500$ & SJIF (Morocco) & $=5.667$ & OAJI (USA) & $=0.350$ \\
\hline
\end{tabular}

3. Chanel-Reynaud, G., \& Bloy, E. (2001). la Banque et le risqu? (p.190). PME. Presses Universitaires de Lyon.

4. (n.d.). Monetary policy. Retrieved 2019, from www.cbu.uz

5. (2016). The situation in the monetary sphere in 2015 and the main directions of monetary policy for 2016. Market, money and credit, Tashkent, №1, 24.

6. Zharkovskaya, E. P. (2010). Banking. Textbook. Moscow: Omega - J1.

7. (n.d.). Exchange rates. site of the Central Bank of the Republic of Uzbekistan. Retrieved 2019, from www.cbu.uz

8. Mirziyoev, S. M. (2017). Critical analysis, strict discipline and personal responsibility should be the daily norm in the activities of each leader. (p.78). Tashkent: Uzbekistan.
9. Tursunov, B. (2017). Ways of increasing the efficiency of usage the production capacity of textile enterprises. Byulleten' nauki i praktiki, (8), 232-242.

10. Karimov, N. G., \& Tashxojaev, M. (2016). Opportunities for the development of the scoring method of consumer lending in Uzbekistan. European journal of economics and management sciences.

https://cyberleninka.ru/search?q=\%D0\%9A\%D 0\%B0\%D1\%80\%D0\%B8\%D0\%BC\%D0\%BE $\% \mathrm{D} 0 \% \mathrm{~B} 2 \% 20 \% \mathrm{D} 0 \% 9 \mathrm{D} \% \mathrm{D} 0 \% \mathrm{BE} \% \mathrm{D} 1 \% 80 \%$ D0\%B1\%D0\%BE\%D0\%B9\%20\%D0\%93\%D0 $\%$ B0\%D0\%BD\%D0\%B8\%D0\%B5\%D0\%B2\% D0\%B8\%D1\%87

11. Ishina, I. V., \& Sazonova, M. N. (2007). Scoring - a model for assessing credit risk. Audit and financial analysis, № 4 . 


\begin{tabular}{|c|c|c|c|c|c|c|}
\hline \multirow{4}{*}{ Impact Factor: } & ISRA (India) & $=3.117$ & SIS (USA) & $=0.912$ & ICV (Poland) & $=6.630$ \\
\hline & ISI (Dubai, UAE & $=0.829$ & РИНЦ (Russia & $=0.156$ & PIF (India) & $=1.940$ \\
\hline & GIF (Australia) & $=0.564$ & ESJI (KZ) & $=\mathbf{5 . 0 1 5}$ & IBI (India) & $=4.260$ \\
\hline & JIF & $=1.500$ & SJIF (Morocco & $=5.667$ & OAJI (USA) & $=0.350$ \\
\hline
\end{tabular}

